УДК 378.147.091.33:811.112.2

DOI:

Олена Ігнатова, кандидат педагогічних наук, дочент кафедри німещької філології Вінницького державного педагогічного університету імені Михайла Коцюбинського

Олеся Жовнич, кандидат педагогічних наук, доцент кафедри методики навчання іноземних мов Вінницького державного педагогічного університету імені Михайла Коиююбинського

\title{
ВИКОРИСТАННЯ ПРАКТИКО-ДОСЛІДНИЦЬКОГО ПРОЄКТУ У ПРОФЕСІЙНІЙ ПІДГОТОВЦІ МАЙБУТНІХ ВЧИТЕЛІВ НІМЕЦЬКОЇ МОВИ ЗАСОБОМ САМОРЕФЛЕКСІї
}

У статті зосереджено увагу на практико-дослідницькому проєкті як ефективному засобі самоаналізу і рефлексії, що сприяє інтеграції трьох складових професійної підготовки майбутніх педагогів: наукової, дослідницької і практичної діяльності, а також рефлексії власної педагогічної діяльності з метою ї̈ подальшоі оптимізації. Аналізуються процес підготовки і проведення студентами практико-дослідницького проєкту, узагальнюються результати роботи, окреслюються перспективи його використання в навчально-освітньому nроиесі.

Ключові слова: практико-дослідницький проєкт; іноземна мова; діяльнісний підхід; професійна підготовка; методично-дидактичні принципи; майбутні вчителі іноземної мови; рефлексія.

Jim. 8.

Olena Ihnatova, Ph.D.(Pedagogy), Associate Professor of the German Philology Department Vinnytsia Mykhailo Kotsiubynskyi State Pedagogical University Olesia Zhovnych, Ph.D.(Pedagogy), Associate Professor of the Methods of Teaching Foreign Languages Department Vinnytsia Mykhailo Kotsiubynskyi State Pedagogical University

\section{THE SELF-REFLEXION OF A FOREIGN LANGUAGE LESSONAS A WAY OF PROFESSIONALIZATION BY EXPERIENCE OF USING THE PRACTICE AND RESEARCH PROJECT}

The article is devoted to the issue of training future German language teachers in pedagogical university at the faculty of Foreign Languages. A key aspect is the practical research project, which is part of the autonomous work of students within the discipline "Methods of teaching a foreign language". The article focuses on the practical research project as an effective way of self-analysis and reflection, which promotes the integration of three components of professional training of future teachers: scientific, research and practical activities, as well as reflection on their own pedagogical activities with further optimizing. The article analyzes the process of preparation and conduct of practical research project by students, summarizes the results of work, and outlines the prospects for the use of practical research project in the educational process. Features of preparation are carried out and the analysis of the practical research project is described; the advantages and disadvantages of the practical research project are noted; the perspectives for its further implementation in the educational process of pedagogical university at the faculty of foreign languages are outlined. The presented research was conducted at Vinnytsia Mykhailo Kotsiubynskyi State Pedagogical University at the faculty of foreign Languages among fourth-year students studying at the bachelor's level in the specialization "Secondary education. Language and literature: German and English".

Keywords: practical research project; foreign language; activity approach; professional training, methodological and didactic principles; future foreign language teachers; reflection.

П остановка проблеми. У 2016 p. Вінницький державний педагогічний університет підписав угоду про кооперацію між ВДПУ імені Михайла Коцюбинського та Гете-Інститутом про співробітництво у підготовці студентів та підвищенні кваліфікації викладачів німецької мови, а також у сприянні розвитку німецької мови у Вінниці. Підписання угоди надало нам можливість готувати наших студентів за новими стандартами у методиці навчання німецької мови, які відповідають вимогам нової української школи. Слід зазначити, що університет був одним 3 перших закладів вищої освіти (3ВО) в Україні, який за сприяння та фінансової підтримки Німеччини успішно пілотував проєкт міжнародної програми "DLL - Вчимося навчати німецької". Ця програма $є$ абсолютно інноваційною за змістом і формою. Акцент ставиться на компетентнісному та комунікативно-діяльнісному підходах до вивчення іноземних мов. У навчання традиційних мовних навичок інтегрована концепція практично

(C) О. Ігнатова, О. Жовнич, 2021 


\section{ВИКОРИСТАННЯ ПРАКТИКО-ДОСЛІДНИЦЬКОГОПРОЄКТУ У ПРОФЕСІЙНІЙПДГОТОВЦ МАЙБУТНІХ ВЧИТЕЛІВ НІМЕЦЬКОӤ МОВИЗАСОБОМ САМОРЕФЛЕКСІЇ}

орієнтованого навчання, а також орієнтація на учня та його залучення до активної роботи. Ефективною $\epsilon$ також форма занять змішаного навчання, що передбачає опрацювання частини матеріалу на онлайн-платформі і дає змогу раціонально використовувати час на аудиторних заняттях.

Підготовка затребуваних висококваліфікованих учителів іноземної мови та пошук шляхів підвищення ефективності процесу їх навчання $€$ одним із ключових завдань як вітчизняної, так і зарубіжної методики викладання іноземних мов. Важливою умовою стає вміння спостерігати, узагальнювати, аналізувати, рефлексувати, оскільки це допомагає вчителю, з одного боку, визначити індивідуальні особливості розвитку учнів, їх інтереси, захоплення і впровадити ці знання в навчальну і виховну діяльність, у позакласну і самостійну роботу учнів з метою їх мотивації до вивчення іноземної мови. 3 іншого, як зазначає Н. Ничкало, наукове спостереження та узагальнення педагогічного досвіду дають можливість вивчати і удосконалювати себе як педагога, узагальнювати об'єктивні закономірності в ході уроку і коригувати їх за необхідності $[8,124]$. Подібного принципу спостереження і рефлексії своєї професійної діяльності дотримуються група методистів ФРН, якій належить концепція практико-дослідницького проєкту як одного 3 ефективних способів підвищення якості підготовки (майбутніх) вчителів німецької мови в рамках міжнародної програми "Deutsch Lehren Lernen” (DLL) [2]. Актуальність дослідження визначається важливістю та необхідністю створення умов для навчання майбутніх вчителів іноземної мови - методам спостереження, самоаналізу і рефлексії для підвищення рівня їх професіоналізації. Одним з таких методів може бути практико-дослідницький проєкт.

Мета статті розглянути і проаналізувати особливості практико-дослідницького проєкту як ефективного способу вдосконалення методичної професійної підготовки майбутніх вчителів іноземної мови засобом саморефлексії.

Для досягнення поставленої мети необхідним $\epsilon$ розв'язання таких завдань: 1) описати особливості підготовки, проведення та аналізу практико-дослідницького проєкту; 2) визначити і описати переваги i недоліки практикодослідницького проєкту, грунтуючись на саморефлексії; 3) визначити перспективи його подальшого впровадження в навчально-освітній процес студентів педагогічних ЗВО на факультеті іноземних мов. Представлене дослідження проводилося у Вінницькому державному педагогічному університеті імені Михайла Коцюбинського на факультеті іноземних мов серед студентів четвертого курсу, які навчаються на освітньому рівні бакалавра за напрямом “Середня освіта. Мова і література: (німецька)".

Аналіз досліджень. Теоретичною базою дослідження у вітчизняній методиці викладання іноземної мови стали роботи О. Бігич, Н. Бориско, С. Ніколаєвої, Л. Морської, які описують досвід використання практико-дослідницьких проєктів 3 метою підвищення рівня професіоналізму вчителів / майбутніх учителів німецької мови [1]. Основою теоретичних положень стали також новітні європейські та німецькі розробки, надані в рамках німецькомовних курсів підвищення кваліфікації для вчителів німецької мови як іноземної “Deutsch Lehren Lernen” (далі DLL) [2; 3; 6]. Базуючись на основній методичній концепції актуальної дидактики іноземної мови варто відзначити такі основні методичні підходи до проведення уроку, як діяльнісний та орієнтаційний: орієнтація на успіх, орієнтація на учнів, орієнтація на дії, орієнтація на завдання, орієнтація на взаємодію, орієнтація на компетентність, контекстуалізація та персоналізація $\epsilon$ також важливими принципами [6]. Останні, зі свого боку, вимагають знання певних процедур і методологічних принципів викладання, таких як відповідний вибір соціальної або робочої форми [3]. Саме тому методологічно-дидактичні принципи змістовно пов'язані $з$ практикодослідницькими проєктами. Дослідницьке і рефлексивне експериментальне навчання у контексті DLL скеровано на взаємодію спостереження і рефлексію власних уроків. Застосування діяльнісного підходу передбачає формулювання конкретного питання [3]. Учасники проєкту знаходять відповіді у процесі проведення практико-дослідницького проекту (РЕР).

Виклад основного матеріалу. Практична значимість дослідження полягає у тому, що у пропонованій статті досвід може сприяти вдосконаленню освітнього процесу і може бути цікавий та корисний для викладачів методики навчання іноземних мов, студентам, які навчаються за напрямом підготовки "Середня освіта (німецька і англійська мови)”, а також для вчителів іноземної мови, які викладають німецьку мову як другу іноземну в загальноосвітніх закладах.

Ключовим моментом в організації автономної роботи учнів є розробка, реалізація і захист практико-дослідного проекту як ефективного методу підвищення професійної компетенції майбутнього вчителя німецької мови. Наразі 


\section{ВИКОРИСТАННЯ ПРАКТИКО-ДОСЛДНИЦЬКОГОПРОЄКТУ У ПРОФЕСІЙНІЙ ПДГОТОВЦІ МАЙБУТНІХ ВЧИТЕЛІВ НІМЕЦЬКОӤ МОВИЗАСОБОМ САМОРЕФЛЕКСІЇ}

практико-дослідницький проєкт є інструментом самоаналізу і саморефлексії діяльності вчителя іноземної мови, який запропонувала група методистів Гете-Інституту ФРН, автори програми підвищення кваліфікації викладачів німецької мови як іноземної "Deutsch Lehren Lernen” (DLL) [2; 3; 6]. У рамках зазначеної програми проєкт відомий як Praxiserkundungsprojekt (РЕР), він дозволяє педагогу самостійно або групою колег спостерігати, вивчати, аналізувати і поліпшувати окремий аспект свого заняття (наприклад, навчання читання, письма, говоріння, аудіювання) або виявляти найбільш гостру педагогічну проблему і розв'язувати їі за допомогою збору, аналізу та опису даних і результатів проекту. У процесі реалізації практикодослідницького проєкту студенти готуються до проведення науково-дослідницької роботи. Тим самим відбувається інтеграція трьох складових професійної підготовки майбутніх педагогів: наукової, дослідницької та практичної діяльності, а також рефлексії власної педагогічної діяльності 3 метою ії подальшої оптимізації [5].

Практично-дослідницькі проєкти можуть бути корисними для розвитку власних навичок викладання як вчителя мови та випробування нових ідей в аудиторії. Для практичної апробації обирається дидактичне питання, яке є важливим для вчителя. Тому практично-дослідницькі проєкти є інструментами навчання протягом усього життя для вчителів, які, як експgерти у навчанні, самі приносять позитивні зміни [4].

Практико-дослідницький проєкт має структуру і виконується відповідно до певних вимог. Він включає в себе тему, проблемне питання, актуальність, мету, завдання, об'єкт, предмет дослідження, що проводиться, методи, матеріал дослідження, опис ходу дослідження, узагальнення його результатів, перспективи подальшого дослідження в обраному напрямуі [6].

DLL базується на концепції дослідження та рефлексивного досвіду учнів, який розвивається завдяки щоденній діяльності та актуальних викликах. Таким чином, центральним методологічним елементом DLL $є$ рефлексія власного уроку. На додаток до сучасних дидактичних знань, німецькі та іноземні школи, Гете-Інститути та університети пропонують імпульси, які покликані стимулювати рефлексію через завдання. Урок не оцінюється, а більше ставиться дослідницьке питання до власного уроку з подальшим обміном думками з іншими учасниками проекту, що динамічно розширює можливості професійної діяльності.
РЕР- проєкт виконується у групах (тандемах або трідемах) і починається 3 визначення теми, сформульованої у вигляді РЕР-питання, а також 3 теоретичного обгрунтування дослідницького проєкту: визначення об'єкта, предмета дослідження, аргументація практичної значущості дослідження опис індикаторів і критеріїв, визначення очікуваних результатів.

Варто виокремити три типи РЕР-питань [7]:

1. Сприйняття ситуації з відповідним питанням “Що і як?” Спостереження чи сприйняття власного предмета дослідження (Bestandsaufnahme-PEP).

2. Зміни (характеризується дослідженням та тестуванням нових речей:

“Що відбувається в моєму класі, коли я намагаюся апробувати X?" (Veränderungs-PEP)

3. Застосування, в якому випробовується невідомий інструмент (Anwendungs-PEP).

Наступним кроком проєктної роботи є планування й проведення практикодослідницького проєкту з учнями в школі і апробація проєкту з описом результатів роботи. Для проведення уроку в рамках проєкту студенти знайомляться 3 класом, в якому вони будуть проводити своє дослідження, з учителем, який веде в даній групі німецьку мову, відвідують кілька занять, оцінюють можливості учнів, темп їх роботи, вивчають матеріал, над яким працює вчитель з учнями. Далі студенти приступають до розробки плану уроку, оформляють його у вигляді таблиці, що відображає тему і мету, етапи уроку і їх цілі, матеріал, дії вчителя та учнів, визначають форми роботи, основні й допоміжні засоби [3]. У запропонованій Гете-Інститутом концепції дана таблиця носить назву “Lehrskizze" [2]. На думку студентів, таке узагальнення всього плану уроку $\epsilon$ для них наочним, зрозумілим, структурованим, а також допомагає з вибором методів, принципів, форм роботи, матеріалів, правильної та логічної послідовності, часу на виконання того чи того завдання. Кожен окремий крок відіграє важливу роль для досягнення мети. "Lehrskizze" стає основним інструментом студентів у підготовці до уроків під час педагогічної діяльності майбутніх молодих фахівців (про це свідчать відгуки випускників 3ВО факультету іноземних мов). Із 30 опитаних респондентів 80 \% вважають, що "Lehrskizze" сприяє зосередженості та розвиває вміння більш якісно і точно ставити цілі уроку, логічно і структуровано планувати етапи, орієнтуватись на відповідний матеріал, задоволеність від проведеного уроку висловлюють 88 \%, що є ще одним доказом результативності.

Організаційні питання полягають у розподілі 


\section{ВИКОРИСТАННЯ ПРАКТИКО-ДОСЛІДНИЦЬКОГОПРОЄКТУ У ПРОФЕСІЙНІЙПІДГОТОВЦІ МАЙБУТНІХ ВЧИТЕЛІВ НІМЕЦЬКОӤ МОВИЗАСОБОМСАМОРЕФЛЕКСІЇ}

обов'язків: хто проводить урок, хто виступає в ролі спостерігача, хто виступає в ролі фото-, відеорепортера (за умови згоди учнів та їх батьків), розробляють всі необхідні анкети, опитувальники, що дозволяють надалі простежити наявність / відсутність змін відповідно до поставленого дослідником завдання, готують дидактичний матеріал тощо), проводять урок, аналізують його результати, описують їх, готують презентації, що відображають всі аспекти практикодослідницького проєкту, і звіт, в якому він описується детально. Вважаємо важливим відзначити, що практико-дослідницький проєкт готується групою, але запланований урок проводиться кожним учасником групи самостійно в різних класах з різних тем. Завдання учасників групи - підтримати один одного в підготовці і зборі матеріалу, фото-, відео-звіту, презентації. Можливість застосовувати диференційований підхід в навчанні робить проєкт ще актуальнішим.

На завершення студенти захищають свої проєкти. Під час захисту вони можуть задавати один одному питання, коментувати проєкти, давати рекомендації. Таке активне обговорення підсумкових робіт курсу стає свого роду узагальненням усієї роботи студентів і демонструє знання, сформовані вміння, навички i компетентності.

На лекційних та семінарських заняттях студентам пропонуються для обговорення ситуації, що продукують можливі теми для педагогічного дослідження і постановки дослідницького питання, визначення методів самоспостереження під час власної педагогічної діяльності, де майбутні педагоги виступають у ролі дослідників. Студенти роблять свій вибір на користь таких тем: “Як зміниться комунікативна активність учнів, якщо на уроці застосувати різні соціальні форми роботи”, “Як відреагують учні, якщо для врегулювання автентичної ситуації запропонувати офіційні вебсторінки”, “Які зміни може встановити вчитель, якщо застосує бумеранг-модель при плануванні уроку” та ін. Практико-дослідницькі проєкти використовуються на завершенні курсу “Методика навчання іноземної мови" і тим самим є звітністю студентів про їх володіння теоретичними положеннями і практичними аспектами курсу.

Аналізуючи досвід проведення студентами практико-дослідницьких проєктів, а саме звітної документації, їхні анкети, розуміємо, що така діяльність має як позитивні, так і негативні сторони. Позитивним вважаємо те, що вони дають студентам можливість відчути себе повноцінними фахівцями, а це у них самостійність і відповідальність за зміст уроку. До того ж, майбутня професійна діяльність аналізується за допомогою спостереження за своїми діями на проведеному уроці або за діями своїх одногрупників, порівняння, зіставлення, аналізу і самоаналізу, що дає імпульс для дослідження проблеми, що виникла, а потім для її подальшого розв'язання.

До безперечних переваг належить і робота над практико-дослідницьким проєктом сприяє практичному освоєнню інноваційних прийомів і методів навчання німецької мови, оволодіння організаційними навичками, рефлексії та корекції освітнього процесу. Самостійне планування уроку, подальший детальний аналіз, постановка проблеми, пошук ії̈ розв'язання вчать майбутніх вчителів іноземної мови критично підходити до аналізу уроку, обгрунтовано оцінювати його успішність. Отже, такі проєкти готують до правильної організації і проведення взаємовідвідувань уроків в колективі вчителів, що стане невід'ємною частиною їх професійної діяльності.

Водночас, важливою складовою позитивного досвіду використання практико-дослідницьких проєктів у процесі підготовки майбутніх вчителів іноземної мови є принцип співробітництва, реалізація якого відбувається під час групової проєктної діяльності. Фідбеки студентів відображають і той важливий момент, що завдяки роботі над практико-дослідницьким проєктом вони вміють розрізняти “результативний урок німецької мови” від “менш результативного уроку”. Цьому сприяє глибокий аналіз проведеного уроку, рефлексія своїх дій і дій учнів на уроці, обмін досвідом під час обговорень результатів проведеного практико-дослідницького проєкту.

Проте, попри зазначені переваги, варто наголосити на певних труднощах, які пов'язані 3 постановкою проблеми практико-дослідницького проєкту, опис його теоретичних положень. У цьому випадку важливою $є$ участь викладача в роботі групи студентів - своєчасне консультування. Результати своїх спостережень у ході проведеного уроку студенти описують впевнено, показують своє вміння критично ставитися до своїх дій на уроці, роблять висновки, пропонують шляхи вирішення. Всі студенти, які брали участь в анкетуванні, вказують на те, що досвід і знання, отриманні на лекційних та семінарських заняттях, вони успішно використовували під час педагогічної практики.

Узагальнивши самостійний досвід роботи 3 практико-дослідницьким проєктом, отриманий на 
курсах підвищення кваліфікації для вчителів німецької мови, і досвід, отриманий в процесі викладання дисципліни “Методика навчання іноземної мови у профільній школі”, вважаємо за необхідне зробити висновок, що практикодослідницький проєкт дає можливість зосередити свою увагу на різних аспектах навчання німецької мови. Оптимізація професійної діяльності вчителя німецької мови досягається у ході проведення практико-дослідницького проєкту, при цьому якість засвоєння матеріалу підвищується.

Висновки. Вивчення і апробація практикодослідницьких проєктів розширює можливості їх використання у навчально-освітньому процесі закладу вищої освіти:

- практико-дослідницький проєкт може бути альтернативою курсових робіт з методики навчання іноземної мови, позаяк структурно і змістовно повною мірою відповідає вимогам, що ставляться до курсових робіт студентів;

- практико-дослідницький проєкт може бути альтернативою звітної документації студентів по завершенні педагогічної та виробничої практики, так як дозволяє оцінити теоретичні знання студента і їх використання в практичних цілях;

- практико-дослідний проект може бути компонентом практичної частини курсових, випускних кваліфікаційних робіт студентів та магістрантів, бо дає змогу повною мірою, з описом цілей, завдань, методів дослідження, вивчити функціонування того чи того методичного аспекту, аналізувати, порівнювати матеріал і робити відповідні висновки;

- означена концепція підготовки молодих кадрів має бути вивчена і в рамках курсів підвищення кваліфікації вчителів або їх перекваліфікації та додаткової освіти, оскільки дає можливість відстежити всі необхідні для викладання німецької мови знання вміння і навички.

Вивчення змісту, понять і принципів уроку дає можливість професійно і фахово викладати іноземну мову. Навчати можна лише через навчання. Цей роздум робить важливість практико-орієнтованої кваліфікації вчителів німецької мови ще більш чіткою: після індивідуальної рефлексії, фаховий дидактичний зміст потребує практичного застосування. Підвищення кваліфікації за програмою DLL та апробація практико-дослідницьких проєктів пропонують методологічно-концептуальну основу для експериментального навчання.

\section{ЛІТЕРАТУРА}

1. Бігич О. Б., Бориско Н. Ф., та ін. Методика навчання іноземних мов і культур: теорія і практика: підручник для студ. класичних, педагогічних і лінгвістичних університетів / за загальн. ред. С. Ю. Ніколаєвої. Київ: Ленвіт, 2013. 590 с.

2. Ballweg S. u. a. DLL 02: Wie lernt man die Fremdsprache Deutsch?: Stuttgart: Ernst Klett Sprachen, 2013. 198 S.

3. Ende K. u. a. DLL 06: Curriculare Vorgaben und Unterrichtsplanung: Buch mit DVD (dll-deutsch lehren lernen: Fort- und Weiterbildung weltweit). Stuttgart: Ernst Klett Sprachen, 2013. 152 S.

4. Жовнич О. В. Дидактичні переваги і новітні тенденції застосування інформаційно-комунікаційних технологій у вищій школі. Молодь і ринок. №7. 2016. С. 150-155.

5. Ігнатова О.М. Інформаційні технології як засіб інтенсифікації вивчення іноземної мови для професійного спілкування стаття. Сучасні інформаційні технологї та інноваційні методики навчання в підготовиі фахівців: методологія, теорія, досвід, проблеми: зб. наук. пр. Випуск 52. Київ-Вінниця: “ТОВ фірма “Планер", 2018. С. 389-393.

6. Funk H., Kuhn Chr. u. a. DLL 04: Aufgaben, Übungen, Interaktion: dll - deutsch lehren lernen: Fort- und Weiterbildung weltweit). Stuttgart: Ernst Klett Sprachen, 2017. 184 S.

7. Legutke M. DLL - Zehn Schritte zum PEP. Available at: https://www.goethe.de/resources/files/ pdf22/dll_10SchrittezumPEP.pdf

8. Ничкало Н.Г. Особливості вдосконалення методичної компетентності викладачів. Актуальні проблеми психологічної та соціальної адаптації в умовах кризового суспільства: матеріали III Всеукраїнського науковопрактичного круглого столу. 2018. С. 124-127.

\section{REFERENCES}

1. Bihych, O. B. \& Borysko, N. F., (2013). Metodyka navchannia inozemnykh mov i kultur: teoriia i praktyka: pidruchnyk dlia stud. klasychnykh, pedahohichnykh i linhvistychnykh universytetiv [Methods of teaching foreign languages and cultures: theory and practice: a textbook for students of classical, pedagogical and linguistic universities]. (Ed.). S. Yu. Nikolaieva. Kyiv, 590 p. [in Ukrainian].

2. Ballweg, S. u. a (2013). DLL 02: Wie lernt man die Fremdsprache Deutsch? [DLL 02: How to learn German as a foreign language?]. Stuttgart, 198 p.[in German].

3. Ende, K. u. a. (2013). DLL 06: Curriculare Vorgaben und Unterrichtsplanung: (dll - deutsch lehren lernen: Fort- und Weiterbildung weltweit). [DLL 06: Curriculum and lesson planning: (dll - learn to teach German: advanced training worldwide)]. Stuttgart, 152 p. [in German]. 


\section{НОВІ ПІДХОДИ ДО ВИКОРИСТАННЯ ІНСТРУМЕНТІВ НАВЧАННЯ В УМОВАХ ДИСТАНЦЙНОЇ ОСВІТИ}

4. Zhovnych, O. V. (2016). Dydaktychni perevahy i novitni tendentsii zastosuvannia informatsiinokomunikatsiinykh tekhnolohii u vyshchii shkoli [Didactic advantages and the latest trends in the use of information and communication technologies in higher education]. Youth \& market. No.7. pp. 150155. [in Ukrainian].

5. Ihnatova, O.M. (2018). Informatsiini tekhnolohii yak zasib intensyfikatsii vyvchennia inozemnoi movy dlia profesiinoho spilkuvannia stattia [Information technology as a means of intensifying the study of a foreign language for professional communication article]. Modern information technologies and innovative teaching methods in training: methodology, theory, experience, problems: Vol. 52. Kyiv-Vinnytsia, pp. 389-393. [in Ukrainian].

6. Funk, H., Kuhn, Chr. u. a. (2017). DLL 04:
Aufgaben, Übungen, Interaktion: (dll - deutsch lehren lernen: Fort- und Weiterbildung weltweit) [DLL 04: Tasks, exercises, interaction: (dll - learn to teach German: further education and training around the world)]. Stuttgart, 184 p. [in German].

7. Legutke, M. (2012). DLL - Zehn Schritte zum PEP. Goethe-Institut [DLL - ten steps to PEP. Goethe Institute]. Available at: https:/www.goethe.de/ resources/files/pdf22/dll_10SchrittezumPEP.pdf [in German].

8. Nychkalo, N.H. (2018). Osoblyvosti vdoskonalennia metodychnoi kompetentnosti vykladachiv [Features of improving the methodological competence of teachers]. Actual problems of psychological and social adaptation of in the conditions of crisis society: Proseedings of the III All-Ukrainian Scientific-Practical round table. pp. 124-127. [in Ukrainian].

Стаття надійшла до редакції 06.05.2021

УДК 378.14:004

DOI:

Ірина Миськів, кандидат педагогічних наук, доцент кафедри іноземних мов Національний університет “Львівська політехніка"

\section{НОВІ ПІДХОДИ ДО ВИКОРИСТАННЯ ІНСТРУМЕНТІВ НАВЧАННЯ В УМОВАХ ДИСТАНЦІЙНОЇ ОСВІТИ}

Стаття присвячена дослідженню проблеми нових підходів до використання педагогічного інструментарію в умовах дистаниійної освіти. Украӥнська система освіти постійно змінюється $i$ удосконалюється з огляду на внутрішні та зовнішні детермінанти, піддається корекиії зміст і форми ї̈ організації задля відповідності кращим світовим та європейським зразкам. Ці процеси вимагають розробки нових стратегій і тактик організачії освітнього прочесу на всіх його рівнях. Вчені підходять до розгляду проблеми освіти в умовах сьогодення комплексно і иілісно, зокрема обтрунтовують змістову складову $i$ тактичні шляхи удосконалення системи освіти на усіх рівнях.

Ключові слова: система освіти; нові підходи; педагогічний інструментарій; дистанційна освіта; онлайн платформи; учні; студенти; пандемія.

Лim. 5.

Iryna Myskiv, Ph.D.(Pedagogy), Associate Professor of the Foreign Languages Department, Lviv Polytechnic National University

\section{NEW APPROACHES TO THE USE OFTEACHING INSTRUMENTS IN THE CONDITIONS OF DISTANCE EDUCATION}

The article is devoted to the research of the problem of new approaches to the use of pedagogical tools in the conditions of distance education. The Ukrainian education system is constantly changing and improving in view of internal and external determinants, the content and forms of its organization are adjusted to comply with the best world and European standards. These processes require the development of new strategies and tactics for organizing the educational process at all levels.

Scientists and educators actively analyze the problems of teaching difficulties, including foreign languages teaching; consider the organization of the teaching process and control of student achievement; substantiate the importance of the activity approach in teaching process; determine the role of problem-based teaching in today's conditions; study the educational possibilities of new teaching aids; determine the prospects and opportunities of distance teaching in all its diversity.

Current research proves that the situation with the organization and results of distance education in Ukraine, as well as in the world is especially difficult, educational institutions were not ready for new challenges, and time did not allow systematic and scientific development of methods, forms and means of distance teaching.

Note the specifics and features of online teaching, in contrast to traditional one. We emphasize that in the 